\title{
Ultrasound Guided Percutaneous Tracheostomy versus Conventional Tracheostomy: Technique and Outcome
}

\author{
NAGLAA M. ALY, M.D.; HEBA A. LABIB AHMED, M.D.; WAEL A. MOHAMED, M.D. and \\ AHMED Y.A. ELBATSH, M.Sc.
}

The Department of Anesthesiology, Intensive Care and Pain Management, Faculty of Medicine, Ain Shams University

\begin{abstract}
Background: In the 21 st century, the majority of tracheostomies are now inserted by the intensivists in the intensive care unit (ICU). It is one of the most frequent procedures performed in critically ill patients. It has been advocated for those requiring prolonged mechanical ventilation because it facilitates weaning by decreasing the work of breathing, decreases the requirement for sedation and may allow for earlier patient mobilization, feeding and physical and occupational therapy.
\end{abstract}

Aim of Study: To evaluate ultrasound guided percutaneous tracheostomy and conventional tracheostomy in critically ill patients regarding effect on outcome (weaning from mechanical ventilation and ICU stay), duration of the technique, success rate and to evaluate incidence of perioperative, early and late complications.

Patients and Methods: Our study is a randomized controlled clinical trial conducted on 40 critically ill patients admitted to the Intensive Care Unit at Ain Shams University Hospitals, from the period from September 2020 until March 2021 they were intubated and mechanically ventilated and required elective percutaneous dilatational tracheotomy.

Results: US-guided group showed fewer procedural complications compared to conventional group. We had faced procedural complications in conventional group in form of 2 $(10 \%)$ of patients suffer from hypoxemia, Pneumothorax, decannulation and post. Tracheal wall injury. $3(15 \%)$ of patients had transient hypotension and false passage. And 5 (25\%) cases of perforation of ETT cuff during insertion, one case $(5 \%)$ of subcutaneous emphysema and $7(35 \%)$ cases of minor bleeding compered to three cases of minor bleeding in US-guided group, one case of decannulation and three case of transient hypotension. No early complications were detected in both study groups; except one case of tube obstruction or displacement in conventional group. According to late complications our analysis illustrates decrease in late complication in US-guided group $2(10 \%)$ versus $4(20 \%)$ in conventional group. In US-guided group only two cases of Stoma site infection resolved by antibiotic and local care. In conventional group there were two case of Tracheoesophageal fistula, one case of Stoma site infection and one case of Tracheoinnominate fistula.

Correspondence to: Dr. Ahmed Y.A. Elbatsh, E-Mail: ahmed.yassin03@gmail.com
Conclusion: Percutaneous dilatational tracheostomy could be a safer procedure when performed by using peri- and preoperative US assistance. The use of US guidance for percutaneous dilatational tracheostomy could reduce the complication rates of the procedure. The ultrasound-guided percutaneous dilatational tracheostomy seems to reduce the late and early complications when compared to the anatomical landmark guided Percutaneous dilatational tracheostomy. Preprocedural US-guided percutaneous dilatational tracheostomy can be considered as a reliable tool to increase safety and improve outcomes of elective tracheostomy.

Key Words: Intensive care unit - Balloon dilation tracheostomy - Before christ.

\section{Introduction}

TRACHEOSTOMY is not a new medical procedure. It has been reported to have been performed as early as 3600 before Christ (BC) based on Egyptian artifacts. In the 4 th century BC, Alexander the Great was given credit for saving a soldier's life by using the tip of his sword to create an opening in the neck [1]

It is a procedure that has evolved over many hundreds of years. In the 21 st century, the majority of tracheostomies are now inserted by the intensivists in the intensive care unit (ICU) [2]

It is one of the most frequent procedures performed in critically ill patients. It has been advocated for those requiring prolonged mechanical ventilation because it facilitates weaning by decreasing the work of breathing, decreases the requirement for sedation and may allow for earlier patient mobilization, feeding and physical and occupational therapy [3].

Prolonged mechanical ventilation is associated with prolonged stays in the (ICU), higher costs, and increased morbidity and mortality [4] . 
On the other hand, tracheostomy is associated with earlier ventilator weaning, decreased incidence of ventilator-acquired pneumonia, mortality or duration of ICU/hospital length of stay, decreased prevalence of deep vein thrombosis, reduced sedation, reduced work of breathing, improved communication and the potential for nutritional intake [5].

Compared with the open surgical technique, percutaneous dilatation tracheostomy (PDT) has been implemented for similar clinical indications such as protection of the larynx and the upper airway, as well as weaning from prolonged mechanical ventilation. PDT was demonstrated to be as safe as the conventional surgical approach in most critically ill patients [6]

Recent studies have suggested that tracheostomy results in fewer oral-labial ulcerations, improves pulmonary toileting, and lowers incidence of pulmonary infections [7].

Tracheostomy, however, is not devoid of risks. Complications may include hemorrhage, stoma infections, pneumothorax, subcutaneous emphysema, tracheal stenosis, tracheomalacia and rarely death [8]

Percutaneous dilatational tracheostomy (PDT) is a widely utilized technique in ICU as it is a safe and cost effective technique. Ultrasound has emerged as potentially useful tool in assisting percutaneous dilatational tracheostomy when factors that increase the technical difficulty of the procedure (morbid obesity, difficult anatomy and cervical spine precautions) are present [9]

Several studies have demonstrated the value of pre-procedure cervical ultrasound in order to improve the safety of percutaneous dilatational tracheostomy [10].

The potential advantages of ultrasound include the ability to identify the cervical vasculature, the size of the thyroid and the tracheal rings, to help identify the most appropriate location for the tracheal puncture site and to guide the needle insertion into the trachea. Unfortunately, ultrasound cannot be used to visualize within the trachea [11].

Complications of tracheostomy placement are infrequent, but can be life threatening, includes both perioperative complications that can occur intra-operatively as well as till the first 24-48 hours post-operatively, Early complications that occurs within the first week following placement, and the late post-operative complications that can occur later $[8]$.

\section{Aim of the work:}

The aim of this work is to evaluate ultrasound guided percutaneous tracheostomy and conventional tracheostomy in critically ill patients regarding effect on outcome (weaning from mechanical ventilation and ICU stay), duration of the technique, success rate and to evaluate incidence of perioperative, early and late complications.

\section{Patients and Methods}

Our study is a randomized controlled clinical trial conducted on 40 critically ill patients admitted to the Intensive Care Unit at Ain Shams University Hospitals, from the period from September 2020 until March 2021 they were intubated and mechanically ventilated and required elective percutaneous dilatational tracheotomy.

Our objective was to evaluate ultrasound guided percutaneous tracheostomy and conventional tracheostomy in critically ill patients regarding effect on outcome (weaning from mechanical ventilation and ICU stay), duration of the technique, success rate and to evaluate incidence of perioperative, early and late complications.

Inclusion criteria: Patients aged 21 years old or more with indication for tracheostomy.

Exclusion criteria: Pregnancy. Age <21 yrs Active cutaneous infection over the proposed tracheotomy site. Distorted anatomy with unidentifiable anatomic land marks. Scar of major neck surgery, hematoma and radiation exposure. Uncontrolled bleeding disorders. Tracheal stenosis. High positive end-expiratory pressure more than $15 \mathrm{~cm}$ $\mathrm{H}_{2} \mathrm{O}$. Recent myocardial infarction. Surgical emphysema. Asthma exacerbation.

All patients enrolled in our study were subjected to the followings:

Demographic data: Age and sex.

Full history: Including history of chronic disease, previous neck surgery, cause of ICU admission, indication of intubation and its duration.

Physical examination: History taking: APersonal History. B- Complete Medical history to determine comorbidities: Diabetes Mellitus (DM). Hypertension (HTN). Heart Failure. Respiratory Failure. Chronic Kidney Disease.

General examination: Height in $\mathrm{cm}$, weight in $\mathrm{kg}$ and calculation of body mass index. Neck circumference in $\mathrm{cm}$. Vital signs including: Mean heart rate before, during and after 10,20 and 30 
minutes of the procedure. Mean arterial blood pressure "MAP" before, during and after 10, 20 and 30 minutes of the procedure. Oxygen saturation before, during and after 10, 20 and 30 minutes of the procedure. End tidal carbon dioxide "ETCO2" before, during and after 10, 20 and 30 minutes of the procedure. Local examination of the neck searching for any anatomical difficulties: Palpable Thyroid Swellings or other palpable neck masses or any palpable pulsating vessels near the site of entry. Short Neck. Difficult Neck Extension (fixed neck). Tracheal Deviation. Patient data on admission and during their ICU stay: Diagnosis on admission: Number of days on MV before the decision of tracheostomy. Indication of tracheostomy: Weaning failure. Cannot protect the airway ICU Scoring systems on admission: Glasgow coma scale (GCS). Acute Physiology and Chronic Health Evaluation (APACHE II) Score. Duration of the procedure. Complications of the procedure (during and after the procedure). Bleeding. Pneumothorax. Tracheoeosophgeal fistula. False passage. Aspiration. Fracture ring of the trachea.

Selective investigations: Coagulation profile (prothrombin activity, international normalized ratio "INR" and activated partial thromboplastin time), Complete blood count, Arterial blood gases analysis and Plain chest X-ray will be done before (the most recent one) and one hour after the procedure.

\section{Patients classification:}

Patients were classified into two groups according to the method of tracheostomy used: Ultrasound guided PDT. Conventional tracheostomy.

Patients preparations:PDT was performed as a planned, elective operative procedure in our ICU and the preoperative planning was as for a patient going to theatre. Prior to the procedure consideration and preparation was made to address the following: (i) Patient; (ii) Staff; (iii) Equipment; and (iv) difficulty or failure. In the two studied groups, all patients were subjected to the following:

A- Informed written consents.

\section{B- Patient Position:}

The neck was extended (unless the patient requires cervical spine precautions) to increase the field of the operation by placing a pillow under the shoulders with the neck moderately extended and relevant landmarks easily identifiable.

C- Fasting.
D- Blood products:

Bloods were up-to-date including group-andsave.

E- Coagulation abnormalities:

Any coagulation abnormalities were corrected if present.

F- The anticoagulant:

Was stopped before the procedure according to its duration of action.

G- Ventilator mode and preoxygenation:

All patients were mechanically ventilated via an orally placed endotracheal tube. Ventilation was performed in mandatory mode. Also all patients were placed on a regimen of $1.0 \mathrm{FIO} 2$ for $10-15$ minutes immediately prior to the procedure (in order to prevent intraoperative hypoxia whether during the procedure or bronchoscopy), during and for 15 minutes postoperatively.

$\mathrm{H}-$ Sedation, analgesia and muscle relaxants:

Drugs that were administered included: propofol $(2-2.5 \mathrm{mg} / \mathrm{kg}, \mathrm{IV})$ or midazolam $(0.04-0.2 \mathrm{mg} / \mathrm{kg}$, IV), fentanyl (25-100mcg/dose over 1-2 minutes IV) and atracurium $(0.4-0.5 \mathrm{mg} / \mathrm{kg}$ over one-minute IV). Local anesthesia with a vasoconstrictor (2\% lidocaine with $1: 100,000$ epinephrine) was infiltrated into the skin and deeper neck tissues to reduce the amount of bleeding and provide analgesia during the procedure.

I- Direct laryngoscopy:

Direct laryngoscopy was performed to all patients prior to starting the procedure to assess the view of the larynx and to assess the difficulty of reintubation. Under direct laryngoscopy and after thorough aspiration of all secretions from the tube and the tracheas well as the oral cavity, the ETT was exchanged with another one with an inner diameter of $7.5 \mathrm{~mm}$ for female or $8.0 \mathrm{~mm}$ for male patients.

\section{J- Sterilization:}

The skin from the chin to below the clavicles was sterilely prepared with either an iodine-based disinfectant or a solution of chlorhexidine. If excessive hair is present, it should be removed immediately prior to skin preparation. Sterile drapes were placed, creating an opening from the top of the larynx to the patient's suprasternal notch.

\section{Equipment and environmental preparation:}

Medical staff performing PDT: Two experienced doctors were required. The designated anesthetist 
was responsible for management of the patient's upper airway, titration of anesthetic drugs and monitoring and control of the patient's physiological parameters (including oxygenation, ventilation and hemodynamic status). The second doctor was the operator who performed the PDT. One further member of staff (e.g. bedside nurse) who is familiar with the procedure was available to act as a runner or assistant.

Monitoring: All standard intensive care monitoring tools were in place and working effectively prior to the procedure including ECG, finger pulse oximeter, non-invasive BP and capnography. Monitoring was used throughout the procedure and afterwards while the patient is receiving MV.

Presence of an ultrasound (US) machine: Preprocedural US in US guided group, allowed identification of cervical vasculature, identification of the puncture site and the selection of tube size and length.

Difficult airway trolley: Our ICU has a complete and maintained difficult airway trolley that is readily accessible in the event of an emergency. To be ready for dealing with any expected complication. It includes (LMA, Bougie, Short handle laryngoscope, McCoy blade, Bag mask ventilation, Oropharyngeal and Nasopharyngeal airways of variable sizes and malleable intubating stylet).

PDT insertion kit: The set that we were used in our ICU to perform PDT was the Ciaglia Blue Rhino® G2 Advanced Percutaneous Tracheostomy

\section{Percutaneous tracheotomy technique:}

In the conventional tracheostomy technique: Percutaneous tracheotomy technique was performed by using Ciaglia Blue Rhino ${ }^{\circledR}$ G2 Advanced Percutaneous Tracheostomy Introducer set (C-PTIS100-HC, BLUERHINO, COOK, USA) ® with the insertion of a suitable sized tracheotomy tube. The set consisted of a puncture needle, a guide wire, a small dilator, and the special Blue Rhino dilator and three curved stylets for placement of the tracheostomy tube.

The endotracheal tube was repositioned above the site of the proposed tracheostomy, then the endotracheal tube cuff was slightly deflated and it was withdrawn or pulled back so that it lies at the level of the cricoid cartilage or just below the vocal cords by the assistant or the designated anesthetist then the ETT cuff was reinflated again. After that the assistant holding the tube with his or her hands continuously throughout the whole procedure.
Blood pressure, cardiac rhythm, arterial hemoglobin saturation and end tidal $\mathrm{CO} 2$ were continuously monitored through the procedure.

The cricoid cartilage was palpated and a one $\mathrm{cm}$ transverse incision was made through the skin and superficial subcutaneous fascia between the first and second or second and third tracheal rings or mid-way between the thyroid cartilage and sternal notch or 1.5 or 2 fingerbreadths from the sterna notch.

The trachea was punctured with a 15-gauge cannula-on-needle in a posterio-caudal direction and tracheal entry of the needle or cannulation was confirmed by aspiration of air into the saline-filled syringe.

After successful placement of the tracheal cannula, a "J" tip guide wire was passed through the cannula into the tracheal lumen; the cannula was then withdrawn, leaving the guide wire in situ.

A well-lubricated initial 14 Frdilator was passed over the guide wire into the trachea to start stoma formation and was later removed.

A guiding catheter (a white plastic sheath) was advanced over the guide wire until the safety ridge of the guiding catheter lay inside the tracheal lumen. Over the guide wire and guiding catheter, the Ciaglia Blue Rhino (a flexible, hollow tube of hard rubber with a special hydrophilic coating), was passed to the appropriate skin marking, resulting in tracheal dilatation. To increase the dilator's external smoothness, it was wetted with a few milliliters of saline solution or distilled water.

Finally, the tracheostomy tube loaded over an appropriate and well-lubricated introducer was inserted through the tracheal stoma. The introducer, the guide wire and the guiding catheter was then removed, leaving the tracheostomy tube in situ.

Correct positioning of the tube was ascertained with auscultation and capnography.

Once the correct position was confirmed, the tracheostomy was secured on the neck, ventilator parameters was reset again.

Continuous hemodynamic monitoring until thirty minutes.

\section{The ultrasound-guided group:}

Prior to PDT, US was used to perform longitudinal sections to locate the cricoid cartilage, the tracheal rings and the puncture site. 
Then perform transversal sections to identify arteries, veins, thyroid gland, trachea and endotracheal tube.

Then visualize the needle in an 'out-of-plane' mode (that is, the needle path was determined by the presence of a distinct acoustic shadow ahead of the needle) on a transversal section of the neck region.

\section{Statistical analysis of the data:}

Data were fed to the computer using IBM SPSS software package version 21.0. Qualitative data were described using number and percent. Comparison between different groups regarding categorical variables was tested using Chi-square test. Quantitative data were described using mean and standard deviation for normally distributed data.

For normally distributed data, comparison between two independent populations was done using independent $t$-test.

Significance test results are quoted as twotailed probabilities. Significance of the obtained results was judged at the 5\% level.

Student (Unpaired-sample) " $t$ " test:It is used during comparison between the means of different sample groups.

Chi-square test: It tests the association between qualitative nominal variables; it is performed mainly on frequencies. It determines whether the observed frequencies differ significantly from expected frequencies.

\section{Results}

Table (1): Comparison between the two studied groups according to sex.

\begin{tabular}{|c|c|c|c|c|c|c|}
\hline \multirow{3}{*}{ Sex } & \multicolumn{4}{|c|}{ Group } & \multicolumn{2}{|c|}{ Chi-square } \\
\hline & \multicolumn{2}{|c|}{ Ultrasound } & \multicolumn{2}{|c|}{ Conventional } & \multirow{2}{*}{$X^{2}$} & \multirow{2}{*}{$\begin{array}{c}p- \\
\text { value }\end{array}$} \\
\hline & $\mathrm{N}$ & $\%$ & $\mathrm{~N}$ & $\%$ & & \\
\hline Male & 15 & 75.00 & 13 & 65.00 & & \\
\hline Female & 5 & 25.00 & 7 & 35.00 & 0.476 & 0.490 \\
\hline Total & 20 & 100.00 & 20 & 100.00 & & \\
\hline
\end{tabular}

N: Number. $\%$ : Percentage. $\mathrm{X}^{2}$ : Chi-Square.

$p$-values: Calculated Probability.

Table (2): Comparison between the two studied groups according to age.

\begin{tabular}{lccccc}
\hline \multirow{2}{*}{ Age } & \multicolumn{2}{c}{ Group } & & \multicolumn{2}{c}{$t$-test } \\
\cline { 2 - 3 } \cline { 5 - 6 } & Ultrasound & Conventional & & $t$ & $\begin{array}{c}p \text { - } \\
\text { value }\end{array}$ \\
\hline Range & $20-74$ & $35-86$ & & \\
Mean \pm SD & $50.650 \pm 17.545$ & $59.600 \pm 13.655$ & -1.800 & 0.080 \\
\hline$t: t$-Test. & $p$-values: Calculated Probability. & & &
\end{tabular}

Table (3): Comparison between the two studied groups according to number of punctures.

\begin{tabular}{|c|c|c|c|c|c|c|}
\hline \multirow{3}{*}{$\begin{array}{l}\text { Number of } \\
\text { puncture }\end{array}$} & \multicolumn{4}{|c|}{ Group } & \multicolumn{2}{|c|}{ Chi-square } \\
\hline & \multicolumn{4}{|c|}{ Ultrasound Conventional } & \multirow{2}{*}{$\mathrm{X}^{2}$} & \multirow{2}{*}{$\begin{array}{c}p- \\
\text { value }\end{array}$} \\
\hline & $\mathrm{N}$ & $\%$ & $\mathrm{~N}$ & $\%$ & & \\
\hline One & 19 & 95.00 & 12 & 60.00 & 7.381 & 0.061 \\
\hline Two & 1 & 5.00 & 4 & 20.00 & & \\
\hline Three & 0 & 0.00 & 3 & 15.00 & & \\
\hline More than Three & 0 & 0.00 & 1 & 5.00 & & \\
\hline Total & 20 & 100.00 & 20 & 100.00 & & \\
\hline
\end{tabular}

$\mathrm{N}$ : Number. \%: Percentage. $\mathrm{X}^{2}$ : Chi-Square.

$p$-values: Calculated Probability.

Table (4): Comparison between the two studied groups according to insertion time and total time of insertion.

\begin{tabular}{|c|c|c|c|c|}
\hline \multirow{2}{*}{$\begin{array}{l}\text { Duration of } \\
\text { procedure }\end{array}$} & \multicolumn{2}{|c|}{ Group } & \multicolumn{2}{|c|}{$t$-test } \\
\hline & Ultrasound & Conventional & $t$ & $\begin{array}{c}p- \\
\text { value }\end{array}$ \\
\hline $\begin{array}{l}\text { Insertion } \\
\text { Time: }\end{array}$ & & & & \\
\hline $\begin{array}{l}\text { Range } \\
\text { Mean } \pm S D\end{array}$ & $\begin{array}{l}2.9-5.55 \\
3.853 \pm 0.632\end{array}$ & $\begin{array}{l}3.2-8.5 \\
4.779 \pm 1.442\end{array}$ & -2.631 & $0.012 *$ \\
\hline $\begin{array}{l}\text { Total time: } \\
\text { Range } \\
\text { Mean } \pm \text { SD }\end{array}$ & $\begin{array}{l}3.9-7.5 \\
5.745 \pm 0.971\end{array}$ & $\begin{array}{l}3.2-8.5 \\
4.779 \pm 1.442\end{array}$ & 2.484 & $0.018^{*}$ \\
\hline
\end{tabular}

t: $t$-Test. $\quad p$-values: Calculated Probability.

Table (5): Comparison between the two studied groups according to mean heart rate before, during and after the procedure.

\begin{tabular}{|c|c|c|c|c|}
\hline \multirow{2}{*}{$\begin{array}{l}\text { Mean HR } \\
\text { (b/min.) }\end{array}$} & \multicolumn{2}{|c|}{ Group } & \multicolumn{2}{|c|}{$t$-test } \\
\hline & Ultrasound & Conventional & $t$ & $\begin{array}{c}p- \\
\text { value }\end{array}$ \\
\hline \multicolumn{5}{|l|}{ Before: } \\
\hline Range & $92-107$ & $91-105$ & 1.250 & 0.219 \\
\hline Mean \pm SD & $98.050 \pm 4.395$ & $96.300 \pm 4.462$ & & \\
\hline \multicolumn{5}{|l|}{ During: } \\
\hline Range & $95-111$ & $94-111$ & 0.436 & 0.665 \\
\hline Mean \pm SD & $102.200 \pm 4.753$ & $101.500 \pm 5.375$ & & \\
\hline \multicolumn{5}{|l|}{ After } \\
\hline \multicolumn{5}{|l|}{10 Minutes: } \\
\hline Range & $93-109$ & $93-110$ & -0.064 & 0.949 \\
\hline Mean \pm SD & $100.300 \pm 4.813$ & $100.400 \pm 5.020$ & & \\
\hline \multicolumn{5}{|l|}{ After } \\
\hline \multicolumn{5}{|l|}{20 Minutes: } \\
\hline Range & $93-109$ & $93-109$ & 0.544 & 0.590 \\
\hline Mean \pm SD & $99.500 \pm 4.915$ & $98.650 \pm 4.966$ & & \\
\hline \multicolumn{5}{|l|}{ After } \\
\hline \multicolumn{5}{|l|}{30 Minutes: } \\
\hline Range & $90-106$ & $91-107$ & 0.691 & 0.494 \\
\hline Mean \pm SD & $98.400 \pm 4.083$ & $97.450 \pm 4.594$ & & \\
\hline
\end{tabular}

$t: t$-Test. $\quad p$-values: Calculated Probability. 
Table (6): Comparison between the two studied groups according to MAP during the procedure.

\begin{tabular}{lllll}
\hline $\begin{array}{l}\text { Mean ABP } \\
(\mathrm{mmHg})\end{array}$ & Ultrasound & Conventional & & $t \quad \begin{array}{c}p \text {-test } \\
\text { value }\end{array}$ \\
\cline { 2 - 3 } & & & &
\end{tabular}

\begin{tabular}{lllll}
\hline $\begin{array}{l}\text { Before: } \\
\text { Range }\end{array}$ & $75-90$ & $76-90$ & 0.401 & 0.690 \\
Mean \pm SD & $84.050 \pm 4.513$ & $83.500 \pm 4.149$ & & \\
During: & & & & \\
Range & $55-90$ & $55-88$ & -0.063 & 0.950 \\
Mean \pm SD & $78.900 \pm 10.437$ & $79.100 \pm 9.602$ & &
\end{tabular}

After

10 Minutes:

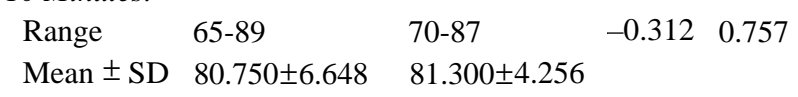

After

20 Minutes:

$\begin{array}{lllll}\text { Range } & 75-90 & 76-87 & 0.319 & 0.751 \\ \text { Mean } \pm \text { SD } & 82.450 \pm 4.430 & 82.050 \pm 3.426 & & \end{array}$

After

30 Minutes:

\begin{tabular}{lllll} 
Range & $74-90$ & $75-86$ & 0.888 & 0.380 \\
Mean \pm SD & $83.250 \pm 4.898$ & $82.050 \pm 3.546$ & & \\
\hline
\end{tabular}

$t$ : $t$-Test. $\quad p$-values: Calculated Probability.

Table (7): Comparison between the two studied groups according to $\mathrm{O}_{2}$ saturation during the procedure.

\begin{tabular}{|c|c|c|c|c|}
\hline \multirow{2}{*}{$\begin{array}{l}\text { Oxygen } \\
\text { Saturation } \\
(\%)\end{array}$} & \multicolumn{2}{|c|}{ Group } & \multicolumn{2}{|c|}{$t$-test } \\
\hline & Ultrasound & Conventional & $t$ & $\begin{array}{c}p- \\
\text { value }\end{array}$ \\
\hline
\end{tabular}

\begin{tabular}{lllll}
\hline $\begin{array}{l}\text { Before: } \\
\text { Range }\end{array}$ & $98-100$ & $98-100$ & 0.600 & 0.552 \\
Mean \pm SD & $99.350 \pm 0.671$ & $99.200 \pm 0.894$ & & \\
During: & & & & \\
Range & $97-100$ & $97-100$ & 1.674 & 0.102 \\
Mean \pm SD & $98.450 \pm 0.945$ & $97.950 \pm 0.945$ & & \\
After & & & & \\
10 Minutes: & & & & \\
Range & $97-99$ & $97-99$ & 0.714 & 0.479 \\
Mean \pm SD & $98.300 \pm 0.571$ & $98.150 \pm 0.745$ & & \\
After & & & & \\
20 Minutes: & & & & \\
Range & $98-100$ & $97-100$ & 1.881 & 0.068 \\
Mean \pm SD & $98.650 \pm 0.587$ & $98.200 \pm 0.894$ & & \\
After & & & & \\
30 Minutes: & & & & \\
Range & $98-100$ & $98-100$ & 0.919 & 0.364 \\
Mean \pm SD & $99.300 \pm 0.571$ & $99.100 \pm 0.788$ & & \\
\hline
\end{tabular}

$t$ : $t$-Test. $\quad p$-values: Calculated Probability.
Table (8): Comparison between the two studied groups according to End Tidal $\mathrm{Co}_{2}$ during the procedure.

\begin{tabular}{|c|c|c|c|c|}
\hline \multirow{2}{*}{$\begin{array}{l}\text { End Tidal } \\
\mathrm{Co}_{2}(\mathrm{mmHg})\end{array}$} & \multicolumn{2}{|c|}{ Group } & \multicolumn{2}{|c|}{$t$-test } \\
\hline & Ultrasound & Conventional & $t$ & >-value \\
\hline \multicolumn{5}{|l|}{ Before: } \\
\hline $\begin{array}{l}\text { Range } \\
\text { Mean } \pm \text { SD }\end{array}$ & $\begin{array}{l}36-57 \\
41.750 \pm 4.865\end{array}$ & $\begin{array}{l}36-51 \\
40.400 \pm 3.169\end{array}$ & 1.040 & 0.305 \\
\hline \multicolumn{5}{|l|}{ During: } \\
\hline $\begin{array}{l}\text { Range } \\
\text { Mean } \pm \text { SD }\end{array}$ & $\begin{array}{l}37-58 \\
43.550 \pm 4.861\end{array}$ & $\begin{array}{l}39-56 \\
44.000 \pm 3.340\end{array}$ & -0.341 & 0.735 \\
\hline \multicolumn{5}{|l|}{ After } \\
\hline $\begin{array}{l}\text { Range } \\
\text { Mean } \pm \text { SD }\end{array}$ & $\begin{array}{l}37-49 \\
41.350 \pm 3.297\end{array}$ & $\begin{array}{l}40-52 \\
41.250 \pm 2.731\end{array}$ & 0.104 & 0.917 \\
\hline \multicolumn{5}{|l|}{ After } \\
\hline $\begin{array}{l}\text { Range } \\
\text { Mean } \pm \text { SD }\end{array}$ & $\begin{array}{l}37-50 \\
41.050 \pm 3.546\end{array}$ & $\begin{array}{l}38-50 \\
40.350 \pm 2.434\end{array}$ & 0.728 & 0.471 \\
\hline \multicolumn{5}{|l|}{$\begin{array}{l}\text { After } \\
30 \text { Minutes: }\end{array}$} \\
\hline $\begin{array}{l}\text { Range } \\
\text { Mean } \pm \text { SD }\end{array}$ & $\begin{array}{l}37-50 \\
40.900 \pm 3.432\end{array}$ & $\begin{array}{l}36-50 \\
39.500 \pm 2.724\end{array}$ & 1.429 & 0.161 \\
\hline
\end{tabular}

$t$ : $t$-Test. $\quad p$-values: Calculated Probability.

Table (9): Comparison between the two studied groups according to $\mathrm{PaO} 2$ before and after the procedure.

\begin{tabular}{|c|c|c|c|c|}
\hline \multirow{2}{*}{$\begin{array}{l}\mathrm{PaO} 2 \\
(\mathrm{mmHg})\end{array}$} & \multicolumn{2}{|c|}{ Group } & \multicolumn{2}{|c|}{$t$-test } \\
\hline & Ultrasound & Conventional & $t$ & $p$-value \\
\hline \multicolumn{5}{|l|}{ Before: } \\
\hline Range & $220-410$ & $218-477$ & -0.212 & 0.833 \\
\hline Mean \pm SD & $\begin{array}{l}280.600 \pm \\
59.034\end{array}$ & $\begin{array}{l}284.750 \pm \\
64.413\end{array}$ & & \\
\hline \multicolumn{5}{|l|}{ During: } \\
\hline Range & $210-395$ & $179-410$ & 0.762 & 0.451 \\
\hline Mean \pm SD & $\begin{array}{l}262.300 \pm \\
53.360\end{array}$ & $\begin{array}{l}249.500 \pm \\
52.902\end{array}$ & & \\
\hline \multicolumn{5}{|l|}{ After } \\
\hline Range & $200-420$ & $210-420$ & 0.438 & 0.664 \\
\hline Mean \pm SD & $\begin{array}{l}267.100 \pm \\
56.300\end{array}$ & $\begin{array}{l}259.650 \pm \\
51.204\end{array}$ & & \\
\hline
\end{tabular}

$t$ : $t$-Test. $\quad p$-values: Calculated Probability.

Table (10): Comparison between the two studied groups according to $\mathrm{PaCO} 2$ to before and after the procedure.

\begin{tabular}{|c|c|c|c|c|}
\hline \multirow{2}{*}{$\begin{array}{l}\mathrm{PaO} 2 \\
(\mathrm{mmHg})\end{array}$} & \multicolumn{2}{|c|}{ Group } & \multicolumn{2}{|c|}{$t$-test } \\
\hline & Ultrasound & Conventional & $t$ & $p$-value \\
\hline \multicolumn{5}{|l|}{ Before: } \\
\hline Range & $34-55$ & $31-49$ & 0.885 & 0.382 \\
\hline Mean \pm SD & $\begin{array}{l}38.200 \pm \\
5.167\end{array}$ & $\begin{array}{l}36.950 \pm \\
3.634\end{array}$ & & \\
\hline \multicolumn{5}{|l|}{ During: } \\
\hline Range & $35-56$ & $35-54$ & -0.385 & 0.703 \\
\hline Mean \pm SD & $\begin{array}{l}40.000 \pm \\
5.201\end{array}$ & $\begin{array}{l}40.550 \pm \\
3.720\end{array}$ & & \\
\hline \multicolumn{5}{|l|}{ After } \\
\hline Range & $35-51$ & $38-52$ & -2.038 & $0.049 *$ \\
\hline Mean $\pm S D$ & $\begin{array}{l}39.000 \pm \\
4.052\end{array}$ & $\begin{array}{l}41.300 \pm \\
3.011\end{array}$ & & \\
\hline
\end{tabular}

$t: t$-Test. $\quad p$-values: Calculated Probability. 
Table (11): Comparison between the two studied groups according to perioperative complications.

\begin{tabular}{|c|c|c|c|c|c|c|}
\hline \multirow{3}{*}{$\begin{array}{l}\text { Perioperative } \\
\text { complication }\end{array}$} & \multicolumn{4}{|c|}{ Group } & \multicolumn{2}{|c|}{ Chi-square } \\
\hline & \multicolumn{2}{|c|}{ Ultrasound } & \multicolumn{2}{|c|}{ Conventional } & \multirow{2}{*}{$X^{2}$} & \multirow{2}{*}{$p$-value } \\
\hline & $\mathrm{N}$ & $\%$ & $\mathrm{~N}$ & $\%$ & & \\
\hline Cardiopulmonary arrest & 0 & 0.00 & 0 & 0.00 & & - \\
\hline Conversion to surgical technique & 0 & 0.00 & 0 & 0.00 & & \\
\hline Hypoxemia & 0 & 0.00 & 2 & 10.00 & 2.105 & 0.147 \\
\hline Major bleeding & 0 & 0.00 & 0 & 0.00 & & \\
\hline Minor bleeding & 3 & 15.00 & 7 & 35.00 & 2.133 & 0.144 \\
\hline Pneumothorax & 0 & 0.00 & 2 & 10.00 & 2.105 & 0.147 \\
\hline Tube misplacement & 0 & 0.00 & 0 & 0.00 & - & - \\
\hline Pneumomediastinum & 0 & 0.00 & 0 & 0.00 & & \\
\hline False passage & 0 & 0.00 & 3 & 15.00 & 3.243 & 0.072 \\
\hline Subcutaneous emphysema & 0 & 0.00 & 1 & 5.00 & 1.026 & 0.311 \\
\hline Accidental decannulation or Air way loss & 1 & 5.00 & 2 & 10.00 & 0.360 & 0.548 \\
\hline Posterior Tracheal Wall Injury & 0 & 0.00 & 2 & 10.00 & 2.105 & 0.147 \\
\hline Perforation of ETT cuff during insertion & 0 & 0.00 & 5 & 25.00 & 5.714 & $0.017 *$ \\
\hline Transient Hypotension & 3 & 15.00 & 3 & 15.00 & 0.000 & 1.000 \\
\hline
\end{tabular}

N: Number. $\quad \%$ : Percentage. $\quad \mathrm{X}^{2}$ : Chi-Square. $\quad p$-values: Calculated Probability.

Table (12): Comparison between the two studied groups according to early complications.

\begin{tabular}{|c|c|c|c|c|c|c|}
\hline \multirow{3}{*}{ Early complication } & \multicolumn{4}{|c|}{ Group } & \multicolumn{2}{|c|}{ Chi-square } \\
\hline & \multicolumn{2}{|c|}{ Ultrasound } & \multicolumn{2}{|c|}{ Conventional } & \multirow{2}{*}{$X^{2}$} & \multirow{2}{*}{$p$-value } \\
\hline & $\mathrm{N}$ & $\%$ & $\mathrm{~N}$ & $\%$ & & \\
\hline Tube obstruction or Displacement & 0 & 0.00 & 1 & 5.00 & 1.026 & 0.311 \\
\hline Haemorrhage Intra or Extratracheal & 0 & 0.00 & 0 & 0.00 & - & - \\
\hline Overdilatation of stomal opening & 0 & 0.00 & 0 & 0.00 & - & - \\
\hline
\end{tabular}

N: Number. \%: Percentage. $\mathrm{X}^{2}$ : Chi-Square. $\quad p$-values: Calculated Probability.

Table (13): Comparison between the two studied groups according to late complications.

\begin{tabular}{|c|c|c|c|c|c|c|}
\hline \multirow{3}{*}{ Late complications } & \multicolumn{4}{|c|}{ Group } & \multicolumn{2}{|c|}{ Chi-square } \\
\hline & \multicolumn{2}{|c|}{ Ultrasound } & \multicolumn{2}{|c|}{ Conventional } & \multirow{2}{*}{$X^{2}$} & \multirow{2}{*}{$p$-value } \\
\hline & $\mathrm{N}$ & $\%$ & $\mathrm{~N}$ & $\%$ & & \\
\hline Stoma site infection & 2 & 10.00 & 1 & 5.00 & 0.360 & 0.548 \\
\hline Tracheomalacia & 0 & 0.00 & 0 & 0.00 & - & - \\
\hline Tracheoesophageal fistula & 0 & 0.00 & 2 & 10.00 & 2.105 & 0.147 \\
\hline Tracheoinnominate fistula & 0 & 0.00 & 0 & 0.00 & - & - \\
\hline Tracheal stenosis & 0 & 0.00 & 1 & 5.00 & 1.026 & 0.311 \\
\hline
\end{tabular}

$\mathrm{N}$ : Number. \%: Percentage. $\mathrm{X}^{2}$ : Chi-Square. $p$-values: Calculated Probability.

\section{Discussion}

In the 21 st century, the majority of tracheostomies are now inserted by the intensivists in the intensive care unit (ICU) [12] .

It is one of the most frequent procedures performed in critically ill patients. It has been advocated for those requiring prolonged mechanical ventilation because it facilitates weaning by decreasing the work of breathing, decreases the requirement for sedation and may allow for earlier patient mobilization, feeding and physical and occupational therapy [3].
On the other hand, tracheostomy is associated with earlier ventilator weaning, decreased incidence of ventilator-acquired pneumonia, mortality or duration of ICU/hospital length of stay, decreased prevalence of deep vein thrombosis, reduced sedation, reduced work of breathing, improved communication and the potential for nutritional intake [5]

Compared with the open surgical technique, percutaneous dilatation tracheostomy (PDT) has been implemented for similar clinical indications such as protection of the larynx and the upper airway, as well as weaning from prolonged me- 
chanical ventilation. PDT was demonstrated to be as safe as the conventional surgical approach in most critically ill patients [6]

Percutaneous dilatational tracheostomy (PDT) is a widely utilized technique in ICU as it is a safe and cost-effective technique. Ultrasound has emerged as potentially useful tool in assisting percutaneous dilatational tracheostomy when factors that increase the technical difficulty of the procedure (morbid obesity, difficult anatomy and cervical spine precautions) are present [9]

Several studies have demonstrated the value of pre-procedure cervical ultrasound in order to improve the safety of percutaneous dilatational tracheostomy [10].

The potential advantages of ultrasound include the ability to identify the cervical vasculature, the size of the thyroid and the tracheal rings, to help identify the most appropriate location for the tracheal puncture site and to guide the needle insertion into the trachea. Unfortunately, ultrasound cannot be used to visualize within the trachea [11]

In our study, 40 patients were recruited for percutaneous dilatational tracheotomy insertion. They were randomly divided into two groups: 20 patients Undergoes conventional PDT and 20 in guided US group with a mean age of $59.6 \pm 13.6 \mathrm{y}$, and 50.6 $\pm 17.5 y$. Male to Female ratio was $1: 2$ compared to $1: 3$ respectively $(p=0.490)$.

The procedure was easy and successfully decreased time of insertion $(p<0.05)$ and reduced number of punctures. Insertion time was less in US-guided Group 3.9 $\pm 0.6 \mathrm{~min}$ as compared to conventional group $4.8 \pm 1.4 \mathrm{~min}(p<0.012)$. The puncture site was changed in 5\% of US-guided Group, while $40 \%$ of conventional required a change of puncture site.

A previous study in Egypt included 44 patients divided into two equal group the mean age of US guided group was $52.68 \pm 45.78 \mathrm{y}$ and in PDT group $56.14 \pm 16.85 \mathrm{y}$. also they found the procedure was easy $(p<0.05)$ in $84.2 \%$ of US-guided group with less time $(p<0.001)$ as compared to the PDT group. The puncture site was changed in $31.8 \%$ of control group, while none of the US-guided patients required a change of puncture site [13].

On the other hand, Gobatto and colleagues studied on 58 patients to the conventional group and 60 patients to US-guided group, they reported portable ultrasound to be a simple technique for screening of blood vessels and for locating the midline before the procedure, procedure failure was $1.7 \%$ of cases with tracheal punctures median 2 in both groups, and the puncture site was changed in $23.3 \%$ of the US group [14].

Other investigators reported puncture site change in (39) $23.8 \%$ and (14) $23.3 \%$ of the studied US population [15]

In our study the procedure length was shorter in the US-guided group, this coincides with previous authors.

In study of Yavuz et al., and Ravi and Vijay US-guided procedures take more time than controlled group (landmark or bronchoscopy) [11,16]

In study of Rudas et al., on 50 patients using US-guided procedures was associated with high success rate of first pass (87\%) of US-guided group compared to $(58 \%)$ in controlled group $(p=0.028)$ [17].

In the present study, US-guided group showed fewer procedural complications compared to conventional group. We had faced procedural complications in conventional group in form of $2(10 \%)$ of patients suffer from hypoxemia, Pneumothorax, decannulation and post. Tracheal wall injury. 3 $(15 \%)$ of patients had transient hypotension and false passage. And 5 (25\%) cases of perforation of ETT cuff during insertion, one case $(5 \%)$ of subcutaneous emphysema and 7 (35\%) cases of minor bleeding compered to three cases of minor bleeding in US-guided group, one case of decannulation and three case of transient hypotension.

Injury to blood vessels was highlighted in previous studies and they recommended the use of ultrasound to identify them.

Interestingly, a research in London collecting data from computerized tomography (CT) angiography to study neck vasculature; revealed that 187 out of 343 patients $(55 \%)$ verified a pre-tracheal vessel; vein in 131 and artery in 56 [2].

In study of Ahmed et al., they found Us guided group had fewer procedural complication than Conventional group; in Us guided group they had faced $4(21.1 \%)$ of transient hypotension and one case $(5.3 \%)$ of transient hypoxemia compared to three case (13.6\%) of transient of hypoxemia. While in conventional group there were one case (5.3\%) of surgical emphysema, 3 case (13.6\%) of transient hypotension and $8(36.4 \%)$ cases of minor bleeding and hypoxemia [13] 
But in study of Rudas et al. (2014) they found the decrease in procedural complications was not statistically significant $22 \%$ in US guided group versus $37 \%$ in conventional group $(p=0.24)$.

Also, in study of Yavuz et al. (2014) procedural complication was lower in US-guided group 12 (7.8\%) than conventional group 25 (15\%); in USguided group there were $6(3.9 \%)$ cases of minor bleeding, $2(1.3 \%)$ cases of major bleeding and 4 $(2.6 \%)$ cases of transient hypoxemia. While in conventional group $11(6.6 \%)$ cases of minor bleeding, 5 (3\%) cases of major bleeding, 4 (2.6\%) cases of transient hypoxemia, 2 (1.2\%) cases of migration of guide wire and 3 (1.8) cases of cuff perforation.

In the present study, no early complications were detected in both study groups; except one case of tube obstruction or displacement in conventional group.

According to late complications our analysis illustrates decrease in late complication in USguided group $2(10 \%)$ versus $4(20 \%)$ in conventional group.

In US-guided group only two cases of Stoma site infection resolved by antibiotic and local care. In conventional group there were two case of Tracheoesophageal fistula, one case of Stoma site infection and one case of Tracheoinnominate fistula.

Three previous randomized controlled trials compared USPDT with landmark or bronchoscopy guided PDT; the total minor complication rates vary between $11.52 \%$ to $56.75 \%$; without difference between both compared groups $[11,16,17]$

Other authors recruited 12 patients aged (3066), females were $66.67 \%$ patients; they performed PDT guided with the pre-procedural US without complications [18]

Complications in previous studies widely varied; probably attributed to the discrepancy in sample size, candidate population, and different equipment.

\section{Conclusion:}

Percutaneous dilatational tracheostomy could be a safer procedure when performed by using peri- and preoperative US assistance. The use of US guidance for Percutaneous dilatational tracheostomy could reduce the complication rates of the procedure. The ultrasound-guided Percutaneous dilatational tracheostomy seems to reduce the late and early complications when compared to the anatomical landmark guided Percutaneous dilatational tracheostomy. Pre-procedural US-guided percutaneous dilatational tracheostomy can be considered as a reliable tool to increase safety and improve outcomes of elective tracheostomy.

\section{References}

1- SZMUK P., EZRI T., EVRON S., ROTH Y. and KATZ J.: A brief history of tracheostomy and tracheal intubation, from the Bronze Age to the Space Age. In Intensive Care Medicine, 34 (2): 222-228, 2008.

2- REES J., HAROON Y., HOGAN C., SAHA S. and DEREKSHANI S.: The ultrasound neck imaging for tracheostomy study: A study prompting ultrasound screening prior to percutaneous tracheostomy procedures to improve patient outcomes. Journal of the Intensive Care Society, 19 (2): 107-113, 2018.

3- AMBROSINO N. and VITACCA M.: The patient needing prolonged mechanical ventilation: A narrative review. In Multidisciplinary Respiratory Medicine. BioMed. Central Ltd., Vol. 13, Issue 1, 2018.

4- LOSS S.H., De OLIVEIRA R.P., MACCARI J.G., SAVI A., BONIATTI M.M., HETZEL M.P., DALLEGRAVE D.M., De CAMPOS BALZANO P., OLIVEIRA E.S., HÖHER J.A., TORELLY A.P., TEIXEIRA C.: The reality of patients requiring prolonged mechanical ventilation: A multicenter study. Revista Brasileira de Terapia Intensiva, 27 (1): 26-35, 2015.

5- KOCH T., HECKER B., HECKER A., BRENCK F., PREU M., SCHMELZER T., PADBERG W., WEIGAND M.A. and KLASEN J.: Early tracheostomy decreases ventilation time but has no impact on mortality of intensive care patients: A randomized study. Langenbeck's Archives of Surgery, 397 (6): 1001-1008, 2012.

6- MEHTA C. and MEHTA Y.: Percutaneous tracheostomy. In Annals of cardiac anaesthesia. Wolters Kluwer Medknow Publications, 20 (1): 19-25, 2017.

7- ALHAJHUSAIN A., ALI A.W., NAJMUDDIN A., HUSSAIN K., AQEEL M. and EL-SOLH A.A.: Timing of Tracheotomy in Mechanically Ventilated Critically Ill Morbidly Obese Patients. Critical Care Research and Practice, 2014. https://doi.org/10.1155/2014/840638, 2014.

8- CIPRIANO A., MAO M., HON H., VAZQUEZ D., STAWICKI S., SHARPE R. and EVANS D.: An overview of complications associated with open and percutaneous tracheostomy procedures. International Journal of Critical Illness and Injury Science, 5 (3): 179, 2015.

9- AL-ANSARI M.A. and HIJAZI M.H.: Clinical review: Percutaneous dilatational tracheostomy. In Critical Care. BioMed Central Ltd. Vol. 10, Issue 1, 2005.

10- RUDAS M.: The role of ultrasound in percutaneous dilatational tracheostomy. Australasian Journal of Ultrasound in Medicine, 15 (4): 143-148, 2012.

11- RAVI G.C.P.R. and VIJAY W.C.M.N.: Real time ultrasound-guided percutaneous tracheostomy: Is it a better option than bronchoscopic guided percutaneous tracheostomy? Medical Journal Armed Forces India, 71 (2): 158164, 2015.

12- AVERY B. and JANKOWSKI S.: Management of and indications for tracheostomy in care of the critically ill patient. In Surgery (United Kingdom). Elsevier Ltd., 39 (1): 37-47, 2021. 
13- AHMED I.M., ABDALLA A.M. and ABOTALEB U.I.: Pre-procedural ultrasound assessment as a step towards the safety of percutaneous dilatational tracheostomy: A comparative study. Al-Azhar International Medical Journal, 1 (3): 19-24, 2020.

14- GOBATTO ANDRÉ LUIZ NUNES BESEN B.A.M.P., TIERNO P.F.G.M.M., MENDES P.V., CADAMURO F., JOELSONS D., MELRO L., CARMONA M.J.C., SANTORI G., PELOSI P., PARK M. and MALBOUISSON L.M.S.: Ultrasound-guided percutaneous dilational tracheostomy versus bronchoscopy-guided percutaneous dilational tracheostomy in critically ill patients (TRACHUS): A randomized noninferiority controlled trial. Intensive Care Medicine, 42 (3): 342-351, 2016.

15- GOBATTO ANDRÉ L.N., BESEN B.A.M.P., CESTARI M., PELOSI P. and MALBOUISSON L.M.S.: UltrasoundGuided Percutaneous Dilational Tracheostomy: A Systematic Review of Randomized Controlled Trials and Meta-
Analysis. Journal of Intensive Care Medicine, 35 (5): 445-452, 2020.

16- YAVUZ A., YILMAZ M., GÖYA C., ALIMOGLU E. and KABAALIOGLU A.: Advantages of US in percutaneous dilatational tracheostomy: Randomized controlled trial and review of the literature. Radiology, 273 (3): 927-936, 2014.

17- RUDAS M., SEPPELT I., HERKES R., HISLOP R., RAJBHANDARI D. and WEISBRODT L.: Traditional landmark versus ultrasound guided tracheal puncture during percutaneous dilatational tracheostomy in adult intensive care patients: A randomised controlled trial. Critical Care, 18 (5): 1-10, 2014.

18- MITRA S., KAPOOR D., SRIVASTAVA M. and SANDHU H.: Real-time ultrasound guided percutaneous dilatational tracheostomy in critically ill patients: A step towards safety! Indian Journal of Critical Care Medicine, 17 (6): 367-369, 2013.

\title{
الشق الحنجرى عن طريق الجلد باستخل المجام الموجات الفوق صوتية

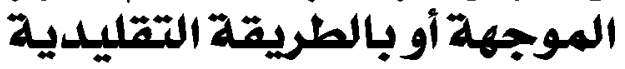

\author{
بداية من القرن الحادى والعشرين، يتم يقوم أطباء الرعاية المركزة بعمل الثق الحنجرى بواحدات الرعاية المركزة.

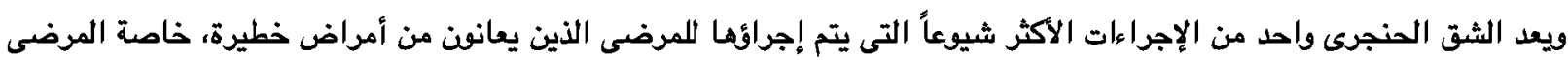

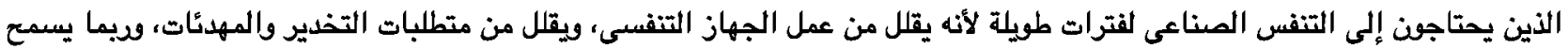 \\ بركة المرضى فى وقت لاحق، والتغذية والعلاج الطبيعى الطئ. \\ والتأ هيل.
}

بالمقارنة مع التقنية الجراحية، يتم تنفيذ الثق الحنجرى عن طريق الجلد للحمول على مؤشرات سريرية مماثلة مثل حماية الحنجرة والمسالك الهوائية العلوية، وكذلك الفطام من التهوية الميكانيكية المطولة. وقد ثبت أنها آمنة مثل النهج الجراحى التهية التقليدى في معظم المرضى الذين يعانون من أمراض خطيرة.

غير أن عملية الشق الحنجرى لا تخلو من المخاطر. قد تشمل المضاعفات النزيف، إلتهابات موضع الثق الحنجرى، استرواح هوائى بالصدر، انتفاخات تصت الجلد، ضيق القصبة الهوائية.

الشق الحنجرى عن طريق الجلد هو تقنية تستخدم على نطاق واسع فى وحدة العناية المركزة لأنها تقنية آمنة و فعالة.

ظهرت الموجات فوق الصوتية كأداة مفيدة محتملة فى عملية الشق الحنجرى عن طريق الجلد عند وجود عوامل تزيد من الصعوبة التقنية

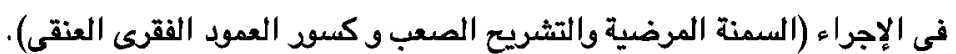
وقد أظهرت العديد من الدراسات قيمة الموجات فوق الصوتية قبل العملية من أجل تحسين سلامة الثق الحنجرى عن طريق الجلد.

وتشمل المزايا المحتملة اللتصوير بالموجات فوق الصوتية القدرة على تحديد الأوعية الدموية، وحجم الغدة الدرقية وحلقات القصبة الهوائية،

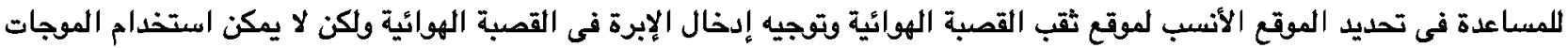
فوق الصوتية لتصور داخل القصبة الهوائية. 